\title{
Knowledge and behavior of professionals about bundled strategies of central venous catheter
}

\author{
Conhecimento e comportamento de profissionais sobre o bundle de cateter venoso central \\ Conocimiento y comportamiento de profesionales sobre el bundle de catéter venoso central
}

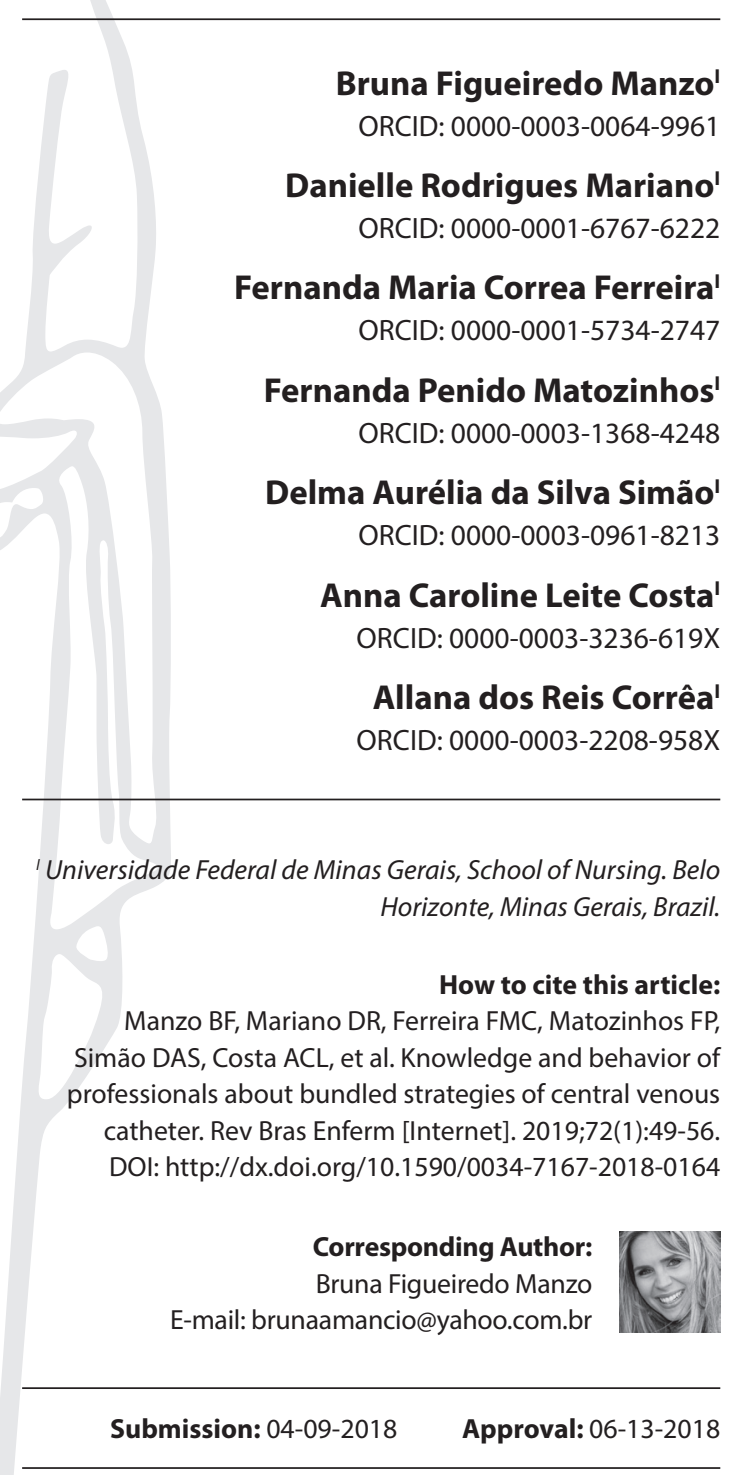

\section{ABSTRACT}

Objective: To investigate the factors that influence the knowledge and behavior of professionals of neonatal and pediatric units about bundled strategies of insertion of central venous catheter. Method: This is a cross-sectional study, conducted in one neonatal and one pediatric intensive care units in a public hospital in Belo Horizonte, Brazil, from April to July, 2016. The sample consisted of 255 professionals who answered a structured instrument. Descriptive and comparative analyses were made using the SPSS software. Results: The category nursing professional $(p=0.010)$, working hours of $12 \times 36$ scale $(p<0.001)$, training as a form of acquiring knowledge $(p<0.001)$ and participation in training programs $(p<0.001)$ are associated to greater knowledge about the bundle. Regarding behavior, no significant associations were observed. Conclusion: The study showed that there are factors that influence the knowledge about bundled strategies of insertion of central venous catheter, reflecting the need to consider these practices for making more effective educational practices in health care. Descriptors: Central Venous Catheterization; Patient Safety; Infant; Child; Nursing.

\section{RESUMO}

Objetivo: Investigar os fatores que influenciam o conhecimento e comportamento dos profissionais de unidades neonatais e pediátricas sobre o bundle de inserção do cateter venoso central. Método: Estudo transversal, realizado em duas unidades de terapia intensiva neonatal e pediátrica de um hospital público de Belo Horizonte, no período de abril a julho de 2016. A amostra constituiu-se de 255 profissionais, que responderam a um instrumento estruturado. Foram realizadas análises descritivas e comparativas por meio do software SPSS. Resultados: A categoria profissional de enfermeiro $(p=0,010)$, a jornada de trabalho de $12 \times 36$ horas $(p<0,001)$, o treinamento como forma de aquisição do conhecimento $(p<0,001)$ e a participação em treinamentos $(p<0,001)$ estão associados ao maior conhecimento sobre o bundle. Quanto ao comportamento, não se observou associações significativas. Conclusão: Revelou-se que existem fatores que influenciam o conhecimento sobre o bundle de inserção de cateter central, refletindo a necessidade de considerá-los para a realização de práticas educativas mais efetivas em saúde.

Descritores: Cateterismo Venoso Central; Segurança do Paciente; Recém-Nascido; Criança; Enfermagem.

\section{RESUMEN}

Objetivo: Investigar los factores que influencian el conocimiento y comportamiento de los profesionales de unidades neonatales y pediátricas sobre el bundle de inserción del catéter venoso central. Método: Estudio transversal que se realizó en dos unidades de terapia intensiva neonatal y pediátrica de un hospital público de Belo Horizonte, en el período de abril a julio de 2016. La muestra se constituyó de 255 profesionales, que respondieron a un instrumento estructurado. Se realizaron análisis descriptivos y comparativos por medio del software SPSS. Resultados: La categoría profesional de enfermero $(p=0,010)$, la jornada de trabajo de $12 \times 36$ horas $(p<$ $0,001)$, el entrenamiento como forma de adquisición del conocimiento $(p<0,001)$ y la participación en entrenamientos $(p<0,001)$ se asocian al mayor conocimiento sobre el bundle. En cuanto al comportamiento, no se observaron asociaciones significativas. Conclusión: Se ha revelado que existen factores que influencian el conocimiento sobre el bundle de inserción de catéter central, reflejando la necesidad de considerarlos para la realización de prácticas educativas más efectivas en salud.

Descriptores: Cateterismo Venoso Central; Seguridad del Paciente; Recién Nacido; Niño; Enfermería. 


\section{INTRODUCTION}

The use of central venous catheters (CVC), mainly peripherally inserted central catheters (PICC), is essential to assist infants and children admitted in intensive care units (ICU), since it enables the safe and continuous administration of intravenous fluids, especially of those that are vesicant or cause irritation to the intimate layer of veins, such as long-term parenteral nutrition, amines and antibiotics. Peripherally inserted central catheter devices are usually the first choice when considering centrally inserted catheters due to presenting smaller risks of complications when compared to others. Despite the benefits of this device, it presents different associated risks, including primary bloodstream infections (BSI), which are among the most frequent health care-related infections ${ }^{(1-2)}$.

The invasiveness and complexity of this type of catheter demands specific scientific and technical knowledge from the multidisciplinary team for its insertion, maintenance and removal, thus preventing complications and providing safe and quality health care ${ }^{(1)}$. The PICC device must be inserted by a doctor or trained nurse.

Improper insertion and maintenance practices of $\mathrm{CVC}$ in a patient may contribute to the increase of infections and, consequently, of morbidity and mortality, hospitalization time and costs of hospitalization of pediatric and neonatal patients ${ }^{(3)}$. Studies show that the primary BSIs in pediatrics and neonatology range from 11.6 to 35.2 per 1000 catheter/day ${ }^{(3)}$, indexes that could be reduced through planning and systematic use of preventive measures, resulting in the reduction of infection rates associated with CVC and, consequently, improvements on quality and safety of health care ${ }^{(2,4-5)}$.

Among strategies developed to reduce the incidence of primary BSIs associated with CVC, the guidelines proposed by the Centers for Disease Control and Prevention (CDC) called Guidelines for the prevention of intravascular catheter-related infections ${ }^{(5-6)}$, as well as bundled strategies, which foresee the use of three to five interventions with high evidence level that must be systematically applied by the team at every health care stage ${ }^{(5-6)}$. When implemented simultaneously, these scientific-based interventions effectively reduce primary $\mathrm{BSI} / \mathrm{s}^{(2,6)}$.

Care procedures foreseen in bundled strategies for CVC insertion are: hand hygiene; maximum barrier precautions (use of hat, mask, cloak, sterile gloves and large sterile fields); preparing the skin with $2 \%$ chlorhexidine; insertion site selection, avoiding the femoral site; and daily review of the need for CVC maintenance ${ }^{(7-8)}$.

Ensuring patient safety in pediatrics and neonatology is critical to provide quality health care. However, despite the recommendation for the application of bundled CVC strategies, the occurrence of adverse events related to catheter infections is still found, being caused the combination work processes failures ${ }^{(8-11)}$. Given this context, the following question arises: what factors may influence the knowledge and behavior of neonatal and pediatric units professionals regarding bundled strategies for the insertion of CVC? The emphasis of this study on primary BSIs derives from the wide use of this device in pediatric and neonatology units when compared to other CVC apparatuses due to lower chances of causing complications to patients.

Given the high rate of catheter-related sepsis in this type of study site, educating professionals of the area on the importance of the proper insertion and maintenance practice of CVC in pediatric and neonatology units is critical. The results of this study can also serve to guide the training of health professionals, aiming at safer health care procedures for infants and children using this device.

\section{OBJECTIVE}

To investigate the factors that influence the knowledge and behavior of professionals of neonatal and pediatric units about bundled strategies for the insertion of central venous catheter (CVC).

\section{METHOD}

\section{Ethical aspects}

This study was approved by the Research Ethics Committee of Universidade Federal de Minas Gerais. All ethical aspects were in accordance with the recommendations of Resolution No. 466 of December 12, 2012, of the Brazilian National Health Council. Data collection occurred through the signature of informed consent form, preserving the anonymity of the participants.

\section{Design, study site, and period}

This is a cross-sectional study, conducted in pediatric and neonatal intensive care units (ICU) of a hospital in Belo Horizonte, Minas Gerais, Brazil, a reference hospital in pediatrics in this state data were collected in the period from April to July 2016.

\section{Sample}

The target population of the study were medics, nurses and nurse technicians involved with insertion activities, maintenance of peripherally inserted central catheters (PICC) in pediatric and neonatal intensive care units (ICU). Professionals were selected from nominal listing provided by the heads of the two sectors ( $\mathrm{n}$ $=270$ ). Inclusion criteria were: performing health care activities related to the insertion and management of PICCs and being assigned to the mentioned sectors cited during the data collection period. Exclusion criteria were: professionals who were on maternity or work leave. The final sample were 255 professionals, considering 15 losses: two people who were on maternity leave and 13 people who refused to participate in the study.

\section{Study protocol}

For data collection, the instrument used was a questionnaire prepared by the authors, being based on the recommendations of the Guidelines for the prevention of intravascular catheter-related infections ${ }^{(5)}$. Prior to the application of the instrument on the sample, it was submitted to the evaluation of three experts, two masters and one PhD. Following, a pilot test was conducted with five professionals of the nursing team to verify the clarity and applicability of the instrument. Certain adjustments had to be done on the instrument regarding understanding difficulties of some items, which were exposed by the professionals who participated in the pilot test.

The instrument was thus divided into two parts, the first comprising demographic and professional characterization considering the variables of gender, age, professional category, 
training time, unit of performance, time of performance in the institution, time of performance in the unit, work shift, working hours, employment regime, form of knowledge acquisition about the bundled strategy of insertion and participation in training programs on infection prevention. The second part comprised items that assessed the behavior about bundled strategies of insertion of central venous catheters (CVC), with the parameters: hand hygiene, assessment about the need for maintenance of the device, use of maximum protection barriers (hat, mask, cloak, sterile gloves and large sterile fields), insertion site analysis, avoiding the femoral region, antisepsis with antiseptic and alcohol-based chlorhexidine or povidone-iodine solution and waiting time of two minutes before insertion. All items were measured by Likert scale ( 1 = never, 2 = sometimes and 3 = always).

The question about self-reported knowledge - "How do you classify your knowledge about bundled strategies?" - was also structured in Likert scale ( $1=$ great, $2=$ good, $3=$ little and $4=$ none), was taken as an outcome variable for comparing professionals regarding their behavior about the bundled strategy for CVC.

Data were collected at the units considering the three shifts of team performance. The completion of this self-applicable questionnaire had an average duration of 10 minutes.

\section{Analysis of results and statistics}

Data were analyzed in the software SPSS, version 22.0, using descriptive, analytical and correlational statistics, considering a $5 \%$ significance level.

First, normality tests were performed and showed the continuous variables of the study as non-parametric. Thus, in the descriptive analysis of socio-demographic variables were used the median, its minimum and maximum values and percentiles for discrete variables and absolute and relative frequencies for categorical variables.

For comparative analyses, professionals in the sample were allocated primarily into two groups according to the self-reported level of knowledge about the bundled strategy: great/good ( $\mathrm{n}=$ 203) and little/no ( $n=52)$.

Comparative analysis between the occupational categories responsible for the insertion of the CVC were also conducted. In this case, to compare nurses $(n=47)$ and doctors $(n=26)$ of both sectors, a Chi-square test was used and, when appropriate, Fisher's exact test to compare the proportions and verify the associations.

Results are presented in tables.

\section{RESULTS}

In general, the study sample was composed of employees with statutory link (78\%), working mostly during the night shift (45.9\%), predominantly female $(94.1 \%)$, with age ranging from 21 to 65 years (median $=36$ years), operating mainly in neonatal intensive care unit (85.1\%) and who had higher education training time for more than eleven years (46.7\%).

Most professionals were vocational education-level professionals (nursing technicians), and higher education-level professionals (doctors and nurses) were $30.6 \%$ of the sample (Table 1).

Table 2 presents the comparison between the professionals who reported their own knowledge level as great/good and those who reported having little/no knowledge, according to the socio-demographic characteristics of the sample.

Table 1 - Sample profile $(\mathrm{N}=255)$, from two intensive care units of a hospital in Belo Horizonte, Minas Gerais, Brazil, 2016

\begin{tabular}{|c|c|c|}
\hline \multicolumn{2}{|c|}{ Parameter } & \multirow{2}{*}{$\begin{array}{c}\text { n (\%) } \\
58(22.7)\end{array}$} \\
\hline Age (in years) & $21-31$ & \\
\hline & $32-42$ & $138(54.1)$ \\
\hline & $43-53$ & $50(19.6)$ \\
\hline & $54-65$ & $9(3.6)$ \\
\hline \multirow[t]{2}{*}{ Gender } & Female & $240(94.1)$ \\
\hline & Male & $15(5.9)$ \\
\hline \multirow[t]{3}{*}{ Professional category } & Nurse & $50(19.6)$ \\
\hline & Doctor & $28(11)$ \\
\hline & Nursing technician & $177(69.4)$ \\
\hline \multirow[t]{2}{*}{ Work unit } & Pediatric ICU* & $38(14.9)$ \\
\hline & Neonatal ICU* & $217(85.1)$ \\
\hline \multirow[t]{4}{*}{ Training time } & $1-3$ years & $27(10.6)$ \\
\hline & 4-7 years & $47(18.4)$ \\
\hline & $8-11$ years & $62(24.3)$ \\
\hline & $>11$ years & $119(46.7)$ \\
\hline \multirow[t]{5}{*}{ Time of practice in the institution } & $<1$ year & $14(5.5)$ \\
\hline & $1-3$ years & $72(28.3)$ \\
\hline & 4-7 years & $74(29)$ \\
\hline & 8-11 years & $60(23.5)$ \\
\hline & $>11$ years & $35(13.7)$ \\
\hline \multirow[t]{5}{*}{ Time of practice in the unit } & $<1$ year & $22(8.6)$ \\
\hline & $1-3$ years & $73(28.6)$ \\
\hline & 4-7 years & $73(28.6)$ \\
\hline & $8-11$ years & $57(22.4)$ \\
\hline & $>11$ years & $30(11.8)$ \\
\hline \multirow[t]{4}{*}{ Work shift } & Morning & $28(11)$ \\
\hline & Afternoon & $11(4.3)$ \\
\hline & Daytime & 99 (38.8) \\
\hline & Nighttime & $117(45.9)$ \\
\hline \multirow[t]{6}{*}{ Working hours } & $12 \times 36$ hours & $110(43.1)$ \\
\hline & $12 \times 60$ hours & $21(8.2)$ \\
\hline & $12 \times 72$ hours & $36(14.1)$ \\
\hline & 6-8-hour shift & $24(9.4)$ \\
\hline & 12-hour shift & $63(24.8)$ \\
\hline & 4-hour shift & $1(0.4)$ \\
\hline \multirow[t]{4}{*}{ Employment relationship } & CLT employee & $17(6.7)$ \\
\hline & Statutory (public sector) & $199(78)$ \\
\hline & Administrative contract & $23(9)$ \\
\hline & Other & $16(6.3)$ \\
\hline
\end{tabular}

Results indicate that the professional category, working hours, form of acquisition of knowledge and participation in training programs on the prevention of infections, were significantly associated $(p<0.05)$ to the knowledge level about bundled strategies. It was found that nurses reported highest percentage in great/good knowledge in relation to little/no knowledge ( $\mathrm{n}$ $=47,94.0 \%)$ when compared to nursing technicians $(n=137$, $77.4 \%)$ and medics ( $n=19,67.9 \%)$. 
Table 2 - Factors associated with the self-reported knowledge level of intensive care unit professionals of a hospital in Belo Horizonte, Minas Gerais, Brazil, $2016(\mathrm{~N}=255)$

\begin{tabular}{|c|c|c|c|c|}
\hline Parameter & & $\begin{array}{c}\text { Good/great knowledge } \\
n(\%)(n=203)\end{array}$ & $\begin{array}{c}\text { Little/no knowledge } \\
n(\%)(n=52)\end{array}$ & $\underset{\text { value }}{p}$ \\
\hline Age (years) & $\begin{array}{l}21-31 \\
32-42 \\
43-53 \\
54-65\end{array}$ & $\begin{array}{c}42(20.7) \\
114(56.2) \\
39(19.2) \\
8(3.9)\end{array}$ & $\begin{array}{c}16(30.8) \\
24(46.2) \\
11(21.2) \\
1(1.8)\end{array}$ & $0.366^{*}$ \\
\hline Gender & $\begin{array}{l}\text { Male } \\
\text { Female }\end{array}$ & $\begin{array}{c}11(5.4) \\
192(94.6)\end{array}$ & $\begin{array}{c}4(7.7) \\
48(92.3)\end{array}$ & $0.516^{\#}$ \\
\hline Professional category & $\begin{array}{c}\text { Nurse } \\
\text { Doctor } \\
\text { Nursing technician }\end{array}$ & $\begin{array}{c}47(23.1) \\
19(9.4) \\
137(67.5)\end{array}$ & $\begin{array}{c}3(5.8) \\
9(17.3) \\
40(76.9)\end{array}$ & $0.010^{*}$ \\
\hline Work shift & $\begin{array}{l}\text { Daytime } \\
\text { Nighttime }\end{array}$ & $\begin{array}{l}111(54.7) \\
92(45.3)\end{array}$ & $\begin{array}{l}27(51.9) \\
25(48.1)\end{array}$ & $0.722^{*}$ \\
\hline Training time & $\begin{array}{l}\text { 1-3 years } \\
\text { 4-7years } \\
8-11 \text { years } \\
>11 \text { years }\end{array}$ & $\begin{array}{l}22(10.8) \\
35(17.2) \\
49(24.2) \\
97(47.8)\end{array}$ & $\begin{array}{c}5(9.6) \\
12(23.1) \\
13(25) \\
22(42.3)\end{array}$ & $0.777^{*}$ \\
\hline Time of practice in the institution & $\begin{array}{c}\text { < 1year } \\
1-3 \text { years } \\
\text { 4-7years } \\
8-11 \text { years } \\
>11 \text { years }\end{array}$ & $\begin{array}{c}8(3.9) \\
62(30.5) \\
56(27.6) \\
50(24.6) \\
27(13.4)\end{array}$ & $\begin{array}{c}6(11.5) \\
10(19.2) \\
18(34.7) \\
10(19.2) \\
8(15.4)\end{array}$ & $0.108^{*}$ \\
\hline Time of practice in the unit & $\begin{array}{l}<1 \text { year } \\
\text { 1-3 years } \\
\text { 4-7years } \\
8-11 \text { years }\end{array}$ & $\begin{array}{c}16(7.9) \\
75(36.9) \\
65(32) \\
47(23.2)\end{array}$ & $\begin{array}{c}6(11.5) \\
14(27) \\
22(42.3) \\
10(19.2)\end{array}$ & $0.528^{*}$ \\
\hline Working hours & $\begin{array}{l}12 \times 36 \text { hours } \\
12 \times 60 \text { hours } \\
12 \times 72 \text { hours } \\
6-8 \text { hour shift } \\
12 \text { hour shift } \\
4 \text { hour shift }\end{array}$ & $\begin{array}{c}88(43.4) \\
14(6.8) \\
33(16.3) \\
23(11.4) \\
44(21.6) \\
1(0.5)\end{array}$ & $\begin{array}{c}19(36.5) \\
11(21.2) \\
2(3.9) \\
1(1.9) \\
19(36.5) \\
0(0)\end{array}$ & $<0.001^{\#}$ \\
\hline $\begin{array}{l}\text { Form of acquisition of knowledge about } \\
\text { bundled strategies }\end{array}$ & $\begin{array}{l}\text { Books/scientific journals } \\
\text { Lectures/courses } \\
\text { Training at the hospital } \\
\text { Others }\end{array}$ & $\begin{array}{c}29(14.3) \\
40(19.7) \\
124(61) \\
10(5)\end{array}$ & $\begin{array}{c}1(1.9) \\
9(17.3) \\
20(38.5) \\
22(42.3)\end{array}$ & $<0.001^{*}$ \\
\hline Training on infection prevention & $\begin{array}{l}\text { Yes } \\
\text { No }\end{array}$ & $\begin{array}{l}127(62.6) \\
76(37.4)\end{array}$ & $\begin{array}{c}5(9.6) \\
47(90.4)\end{array}$ & $<0.001^{*}$ \\
\hline
\end{tabular}

Note: *Chi-square test, "Fisher's exact test.

Regarding working hours, it was found that professionals with $12 \times 36$ hours scale and 12-hour shift self-reported superior values of great/good knowledge when compared to those working $12 \times 60$ scale and 4-hour shift.

Additionally, $61.0 \%(n=124)$ of the sample reported great/ good knowledge about bundled strategies through programs such as training during work, followed by lectures/courses $(19.7 \%$, $n=40)$ and books/journals (14.3\%, $n=29)$.

Regarding professionals who reported knowledge deficit, it must be noted that $90.4 \%(n=47)$ of them reported not having participated in infection prevention training programs.

Analyses of self-reported behavior of doctors and nurses about bundled strategies for CVC insertion showed that its implementation was homogeneously referred to among such professionals for all proposed security items, as shown in Table 3.

From the results, it can be highlighted that all evaluated professionals reported to sanitize their hands before the procedure, as well as to perform the insertion using sterile gloves, mask and hat. Only one respondent reported not using surgical cloak. Regarding the verification of the need for the maintenance of the catheter in the patient and the concern to avoid the femoral site during its insertion, all professionals also reported always performing this action. It must be noted that nursing technicians were not included in these moments because they only participate during the catheter insertion.

Skin antisepsis was also reported by all professionals, having antiseptic and alcohol-based chlorhexidine as the most used - except for three respondents who reported using povidoneiodine solution in infants and children's skin. Regarding the wait of two minutes for the action of chlorhexidine, although it did not show significant difference among professionals, $25.5 \%$ of nurses and $34.6 \%$ of doctors reported performing such practice only a few times or not performing it at all. Regarding the daily verification of the maintenance of the catheter, all professionals reported performing such activity. 
Table 3 - Self-reported behavior about the bundled strategy of insertion, according to professional category $(n=73)$, in two intensive care units of a hospital in Belo Horizonte, Minas Gerais, Brazil, 2016

\begin{tabular}{|c|c|c|c|c|}
\hline Parameter & & $\begin{array}{c}\text { Nurses }{ }^{1}(n=47) \\
n(\%)\end{array}$ & $\begin{array}{c}\text { Doctors }^{1}(n=26) \\
n(\%)\end{array}$ & $\begin{array}{c}p \\
\text { value }\end{array}$ \\
\hline \multirow[t]{2}{*}{ Use of maximum protection barriers } & Always & $47(100)$ & $25(96.2)$ & $0.356^{\#}$ \\
\hline & A few times/never & $0(0)$ & $1(3.8)$ & \\
\hline \multirow{3}{*}{ Use of antiseptic solution } & Antiseptic and alcohol-based chlorhexidine & $22(46.8)$ & $18(69.2)$ & $0.186^{\#}$ \\
\hline & Antiseptic chlorhexidine & $22(46.8)$ & $8(30.8)$ & \\
\hline & Povidone-iodine solution & $3(6.4)$ & $0(0)$ & \\
\hline \multirow[t]{2}{*}{ Waiting two minutes before insertion } & Always & $35(74.5)$ & $17(65.4)$ & $0.412^{*}$ \\
\hline & A few times/never & $12(25.5)$ & 9 (34.6) & \\
\hline
\end{tabular}

Note: *Chi-square test, \#Fisher's exact test. 1Three doctors and two nurses were excluded due to not filling out the items about the items regarding the insertion of central venous catheters.

Despite similar findings about the behavior in relation to bundled strategies of CVC insertion between both professional categories, other analyses comparing the knowledge of nurses and doctors found significant differences between the groups. Among nurses, 93.6\% reported having great or good knowledge about bundled strategies when compared to $69.2 \%$ of doctors $(p=0.013)$. In addition, $46 \%(n=23)$ of nurses reported having already participated in some type of training for infection prevention, whereas among doctors, only $21.4 \%(n=6, p=0.031)$ reported this.

\section{DISCUSSION}

Regarding the results of this study, it can be highlighted that nursing professionals showed good/great self-reported knowledge about bundled strategies. Different findings of other study, developed in a university hospital in Alexandria, Egypt, showed low knowledge of health care professionals regarding the prevention of central venous catheters and low compliance with standard guidelines for the device ${ }^{(12)}$. Another study conducted in a neonatal ICU in Belo Horizonte, 59 catheter insertions were observed and only three procedures followed all the recommendations of the bundled strategy of catheter prevention ${ }^{(13)}$. Thus, the authors showed the importance of the implementation and application of a set of measures and investment in staff training to reduce CVC infection rates. Consequently, a regular scientific-based program of continuing education with a focus on nurses, residents and doctors responsible for catheter insertion and maintenance is essential and can significantly reduce CVC infection rates ${ }^{(2,12-16)}$.

Professionals who reported greater knowledge about the studied object stated that the training they underwent at the institution contributed to the acquisition of information. Thus, simulations for the health team responsible for CVC insertion, manipulation and the continuous monitoring of practices with the device, through the inclusion of a checklist, are important strategies for reducing primary $\mathrm{BSIs}^{(12-14)}$.

Regarding working hours, fewer knowledge about bundled strategies can be related to the team working $12 \times 60$ scales and 4-hour shifts. This suggests that the higher turnover of the team and the fewer working hours in the sector have direct influence on the care provided and increases the need for training and education investments for these professionals ${ }^{(6,17)}$. In addition, training programs for nighttime professionals are relevant since these professionals are in greater numbers and have little turnover due to being public-sector workers. Regarding bundled strategies for CVC, the responsible nurses and doctors reported, with similar values in this study, that they ensure the performance of hand hygiene, the use of maximum barriers, the monitoring on the need for maintenance of the catheter and the sequence for skin antisepsis, in a consistent manner with the guidelines. In an observational study conducted in a tertiary care university hospital in Istanbul, Turkey, professionals were observed and, for 704 general compliance opportunities in total, only $37 \%$ (261/704) were followed. Compliance showed differences by occupational function, $41.4 \%$ and $31.9 \%$ for nurses and doctors, respectively, and the greatest frailty identified was the adherence to the practices of hand hygiene and the use of alcohol-based antiseptic solutions ${ }^{(15)}$.

The Brazilian Multimodal hand hygiene improvement strategy (Estratégia multimodal para a melhoria da higienização das mãos) emphasizes the importance of creating an environment that enables awareness of all people in the implementation of this practice as a top priority ${ }^{(14)}$. However, there are multiple pieces of evidence of low adherence to this procedure. Although the importance of the transmission of health care-related infections due to contact of the hands being accepted worldwide and having its effectiveness proven, compliance with the technical standards for its prevention is unsatisfactory ${ }^{(4,9)}$.

Researchers highlight hand hygiene as a key point of bundled strategies for CVC insertion and state that the main micro-organisms that cause CVC-related infections come from the hands of professionals that handle such device. This preventive measure is associated with the reduction in the rates of infections related to the use of $\mathrm{CVC}^{(6,11,14-15)}$.

Regarding the preparation of skin for the insertion of the device, this study found differences between the behavior of professionals when using antiseptic and alcohol-based chlorhexidine gluconate solution or just chlorhexidine. It is important to note that chlorhexidine gluconate is a low-toxicity antiseptic solution that has chemical affinity with skin and mucosa structures. Furthermore, this solution is widely effective against gram-positive and gram-negative bacteria, presenting bactericide and bacteriostatic action and also acting on some viruses, including HIV ${ }^{(18)}$. The addition of chlorhexidine to alcohol solution may result in residual activity and the microbial action of alcohol leads to the denaturation of proteins, impairing cellular functions ${ }^{(19)}$. 
A study conducted in a ICU points that professionals from the multidisciplinary team consider these as essential materials in the prevention of health care-related diseases and that factors such as lack of, waste and improvisation of materials contribute to non-compliance ${ }^{(20)}$.

The findings of this study are comparable to the findings of other studies conducted with professionals from adult ICU, which reported the knowledge and inappropriate behavior of the team about skin asepsis at even lower percentage values (38.77\% and $49.9 \%$, respectively) $)^{(21-22)}$.

Regarding the monitoring for the maintenance of the catheter, this study showed that the entire team reported performing this action according to the guidelines. Thus, studies discuss and recommend the creation of a checklist for the assessment of the need for devices and daily rounds by the team to define the permanence of the catheter ${ }^{(23-24)}$. Other studies have shown that actions - such as bundled strategies, training of professionals, promotion of a safety culture and its periodic review, monitoring of compliance with measures and monitoring of infection rates with feedback to professionals - are important strategies for reducing infection rates in ICU patients ${ }^{(24-25)}$.

\section{Study limitations}

The assessment of knowledge and behavior through self-report and not through observation can be highlighted as a limitation of this study. Additionally, this is a cross-sectional study, which makes it impossible to identify the temporality of the associations presented in the results.

\section{Contributions to the field of Nursing}

Despite these limitations, this work advances in the perspective of new epidemiological information and in the analysis of data not yet fully explored on the correct insertion and maintenance of CVC in neonatal and pediatric units.

\section{CONCLUSION}

This study shows that the following factors influenced the knowledge about bundled strategies of CVC insertion: professional category, form of knowledge acquisition and undergoing previous training on infection control. This reflects the importance of specific training on the subject, as well as the need for permanent education, focusing on occupational categories more vulnerable to adverse events and with low levels of self-reported knowledge.

The behavior of professionals when considering bundled strategies of insertion showed no statistically significant difference between doctors and nurses; on the other hand, these results report the wide adherence to bundled strategies.

The need of promotion for the effective implementation of the safety culture in these units can be noted, seeking to reduce the number and severity of adverse events in children and infants.

\section{FUNDING}

National Council for Scientific and Technological Development (CNPq).

\section{REFERENCES}

1. Gomes AVO, Nascimento MAL. Central venous catheterization in pediatric and neonatal intensive care units. Rev Esc Enferm USP [Internet]. 2013 [cited 2018 Feb 11];47(4): 794-800. Available from: http://dx.doi.org/10.1590/S0080-623420130000400004

2. Menegueti MG, Ardison KMM, Bellissimo-Rodrigues F, Gaspar GG, Martins-Filho OA, Puga ML, et al. The impact of implementation of bundle to reduce catheter-related bloodstream infection rates. J Clin Med Res [Internet]. 2015 Nov [cited 2018 Feb 14]; 7(11):857-61. Available from: http://dx.doi.org/10.14740/jocmr2314w

3. Greenberg RG, Cochran KM, Smith PB, Edson BS, Schulman J, Lee HC, et al. Effect of catheter dwell time on risk of central line-associated bloodstream infection in infants. Pediatrics [Internet]. 2015 [cited 2018 Feb 14];136:1080-6. Available from: http://dx.doi.org/10.1542/ peds.2015-0573

4. Stocco JGD, Cozeta K, Taminato M, Danski MTR, Meier MJ. Evaluation of the mortality of neonates and children related to the use of central venous catheters: a systematic review. Acta Paul Enferm. [Internet]. 2012 [cited 2018 Feb 11];25(1):90-5. Available from: http://dx.doi. org/10.1590/S0103-21002012000100016

5. O'Grady NP, Alexander M, Dellinger EP, Gerberding JL, Heard SO, Maki DG, et al. Guidelines for the prevention of intravascular catheterrelated infections [Internet]. Atlanta: Centers for Disease Control and Prevention; 2011 [cited 2018 Feb 11]. Available from: https://www.cdc. gov/hai/pdfs/bsi-guidelines-2011.pdf

6. Taylor JE, McDonald SJ, Tan K. Prevention of central venous catheter-related infection in the neonatal unit: a literature review. J Matern Fetal Neonatal Med [Internet]. 2015 [cited 2018 Feb 14];28(10):1224-30. Available from: http://dx.doi.org/10.3109/14767058.2014.949663

7. Pereira B.J.D.; Peterlini M.A.S., Pedreira M.L.G. Care bundle to reduce central venous catheter-related bloodstream infection: an integrative review. Rev Gaúcha Enferm [Internet]. 2012 [cited 2018 Feb 11];33(4):200-10. Available from: http://dx.doi.org/10.1590/ S1983-14472012000400025

8. Marra AR, Noritomi DT, Westheimer Cavalcante AJ, Sampaio Camargo TZ, Bortoleto RP, Durao Junior MS, et al. A multicenter study using positive deviance for improving hand hygiene compliance. Am J Infect Control [Internet]. 2013 [cited 2018 Feb 11];41(11):984-8. Available from: https://www.ncbi.nlm.nih.gov/pubmed/23973423

9. Voos KC, Terreros A, Larimore P, Leick-Rude MK, Park N. Implementing safe sleep practices in a neonatal intensive care unit. J Matern Fetal Neonatal Med [Internet]. 2015 [cited 2018 Feb 14];28(14):1637-40. Available from: http://dx.doi.org/10.3109/14767058.2014.964679 
10. Helder O, van den Hoogen A, de Boer C, van Goudoever J, Verboon-Maciolek M, Kornelisse R. Effectiveness of non-pharmacological interventions for the prevention of bloodstream infections in infants admitted to a neonatal intensive care unit: a systematic review. Int J Nurs Stud [Internet]. 2013 [cited 2018 Feb 11];50(6):819-31. Available from: https://www.ncbi.nlm.nih.gov/pubmed/22385913

11. Erdei C, McAvoy LL, Gupta M, Pereira S, McGowan EC. Is zero central line-associated bloodstream infection rate sustainable? A 5-year perspective. Pediatrics [Internet]. 2015 [cited 2018 Feb 14];135:e1485-93. Available from: http://dx.doi.org/10.1542/peds.2014-2523

12. Alkubati SA, Ahmed NT, Mohamed ON, Fayed AM, Asfour HI. Health care workers' knowledge and practices regarding the prevention of central venous catheter-related infection. Am J Infect Control [Internet]. 2015 [cited 2018 Feb 14];43(1):26-30. Available from: http://dx.doi. org /10.1016/j.ajic.2014.09.021

13. Araújo FL, Manzo BF, Costa ACL, Corrêa AR, Marcatto JO, Simão DAS. Adherence to central venous catheter insertion bundle in neonatal and pediatric units. Rev Esc Enferm USP [Internet]. 2017 [cited 2018 Feb 14];51:e03269. Available from: http://dx.doi.org/10.1590/ S1980-220X2017009603269

14. Brasil (Ministério da Saúde). Measures to prevent infection related to health care [Internet]. Brasília: Agência Nacional de Vigilância Sanitária; 2013 [cited 2018 Feb 14]. Available from: http://pesquisa.bvsalud.org/sms/resource/pt/sms-7551

15. Karaaslan A, Kadayifci EK, Atıcı S, Sili U, Soysal A, Çulha G, et al. Compliance of healthcare workers with hand hygiene practices in neonatal and pediatric intensive care units: overt observation. Interdiscip Perspect Infect Dis [Internet]. 2014 [cited 2018 Feb 14];2014: 306478. Available from: http://dx.doi.org/10.1155/2014/306478

16. Santos SF, Viana RS, Alcoforado CLGC, Campos CC, Matos SS, Ercole FF. Actions in the prevention of central venous catheter-related infections: an integrative review. Rev SOBECC [Internet]. 2014 [cited 2018 Feb 14];19(4):219-25. Available from: http://sobecc.org.br/ arquivos/artigos/2015/pdfs/v19n4/SOBECC_v19n4_219-225.pdf

17. Oliveira F.T., Stipp M.A.C., Silva L.D.; Frederico M., Duarte SCM. Behaviour of the multidisciplinary team about bundle of central venous catheter in intensive care. Esc Anna Nery Rev Enferm [Internet]. 2016 [cited 2018 Feb 14];20(1):55-62. Available from: http://www.scielo.br/ pdf/ean/v20n1/1414-8145-ean-20-01-0055.pdf

18. Marion J, Pavan K, Arruda MEBF, Nakashima L, Morais CAH. Chlorhexidine and its applications in Endodontics: a literature review. Dental Press Endod [Internet]. 2013 [cited 2018 Feb 14];3(3):36-54. Available from: https://www.researchgate.net/ publication/287337747_Chlorhexidine_and_its_applications_in_Endodontics_A_literature_review

19. Oliveira AC, Gama CS. Surgical antisepsis practices and use of surgical gloves as a potential risk factors to intraoperative contamination. Esc Anna Nery Rev Enferm [Internet]. 2016 [cited 2018 Feb 14]; 20(2):370-77. Available from: http://www.scielo.br/pdf/ean/v20n2/en_14148145-ean-20-02-0370.pdf

20. Figueiredo WB, Aquino S, Roberto M. Supply management of an intensive care unit: perception of health professionals about the occurrence of nosocomial infections related to supply failure. Rev Raunp [Internet]. 2016 [cited 2018 Feb 14];8(2):66-84. Available from: http://dx.doi.org/10.21714/raunp.v8i2.1242

21. Alkubati SA, Ahmed NT, Mohamed ON, Fayed AM, Asfour HI. Health care workers' knowledge and practices regarding the prevention of central venous catheter-related infection. Am J Infect Control [Internet]. 2015 [cited 2018 Feb 14];43(1):26-30. Available from: https://www. ncbi.nlm.nih.gov/pubmed/25448304

22. Dedunska K, Dyk D. Prevention of central venous catheter-associated bloodstream infections: A questionnaire evaluating the knowledge of the selected 11 evidence-based guidelines by Polish nurses. Am J Infect Control [Internet]. 2015 [cited 2018 Feb 14];43(12):1368-71. Available from: https://www.ncbi.nlm.nih.gov/pubmed/26307045

23. Perin, D. C. Evidence-based measures to prevent central line-associated bloodstream infections: a systematic review. Rev Lat Am Enfermagem [Internet]. 2016 [cited 2018 Feb 14];24:e2787. Available from: http://dx.doi.org/10.1590/1518-8345.1233.2787

24. Osorio J, Álvarez D, Pacheco R, Gómez CA, Lozano A. Implementation of an insertion bundle for preventing central line-associated bloodstream infections in an intensive care unit in Colombia. Rev Chilena Infectol [Internet]. 2013 [cited 2018 Feb 14];30(5):465-73. Available from: http://dx.doi.org/10.4067/S0716-10182013000500001

25. Cherifi, S, Gerard M, Arias S, Byl B. A multicenter quasi-experimental study: impact of a central line infection control program using auditing and performance feedback in five Belgian intensive care units. Antimicrob Resist Infect Control [Internet]. 2013 [cited 2018 Feb 14];2(1):33. Available from: https://www.ncbi.nlm.nih.gov/pubmed/24308851 